\title{
Research on Professional Spirit Cultivation Mechanism for Young Teachers in Private Colleges
}

\author{
Qiang Dou \\ Xi'an Fanyi University \\ Xi'an, China
}

\begin{abstract}
The professional spirit cultivation of young teachers in private colleges has been a major topic and an urgent mission faced by the private colleges with the profound changes of world situation and the national conditions as well as the continuous advancement of educational reform. This paper describes the demands of the times for strengthening professional spirit of young teachers in private colleges, analyzes the reasons of young teachers' deficiency in professional spirit, and puts forward the strategies for cultivation of professional spirit of young teachers in colleges.
\end{abstract}

\section{Keywords—private college; young teacher; professional spirit}

\section{INTRODUCTION}

$\mathrm{Xi}$ Jinping, the General Secretary, points out that "young teachers are the basement and source of education, bearing the heavy responsibility of ensuring each child to grow up healthily and running education to the satisfaction of people [1]. They form the important part of college teachers, and they are the important force to push the scientific development of college teachers as well as to run the higher education to the satisfaction of people. As a result, their professional spirit not only relates to their own life and career, but also influences students' growth in the future, indicates the development orientation of colleges, and concerns the great cause of national rejuvenation, social progress and "Chinese Dream" realization. With the changes in world situation and national conditions, the diversification of composition of college students and teachers as well as the advancement of educational reform, many new situations and problems occur in the professional spirit of young teachers. Therefore, the professional spirit cultivation of young teachers in colleges has been the major topic and an urgent mission faced by the current colleges.

\section{ANALYSIS OF CURRENT SITUATION OF YOUNG} TEACHERS IN PRIVATE COLLEGES AND THEIR PROFESSIONAL SPIRIT STATE

\section{A. Analysis of Current Situation of Young Teachers in Private Colleges}

1) There are a large number of young teachers, forming

Project Name: Xi'an social science planning project of "Research on Professional Spirit Cultivation Mechanism for Young Teachers in Private Colleges"

Project No.: XF109. the main force of teachers in private colleges: The structure of teachers in private colleges is dumbbell-shaped, with the re-employed teachers after retirement and young teachers holding one end respectively, lacking of the middle-aged teachers seriously. The faculty is younger as a whole, and young teachers form the main body.

2) Young teachers are well-educated yet their specialization degree needs to be enhanced: Most of the young teachers graduate from colleges not for long with higher educational background. Currently, the newly hired teachers in private colleges are mainly the postgraduates with master degree, and the number of teachers with Ph.D degree in private colleges is also rising. The level of educational background of teachers in private colleges is enhanced greatly. However, from the perspective of their professional degree, young teachers have taught for a short period of time with the deficiency of educational experience; and most of them are graduated from public colleges, having insufficient understanding of private colleges' development and students' condition. As a result, the teaching content and teaching method need to be adjusted, so as to meet the development of private colleges and students' demands.

3) Young teachers have a short-time of teaching experience with generally low title: Young teachers are generally just graduated from colleges or they have just been hired with generally low title. The title structure of young teachers in private colleges is not optimistic. At present, some of young teachers are lectures, and most of them are teaching assistants and the teachers without class. The professional title evaluation system for teachers in private colleges is not perfect enough, which is more difficult with respect to the professional title evaluation compared to that of the public colleges. Improvement of professional title evaluation system for teachers in private colleges will render private colleges the same opportunities as that of the public colleges, which will mobilize the enthusiasm for work of the young teachers in private colleges, and that is conducive to the enhancement of education quality of private colleges.

\section{B. Analysis of the Professional Spirit of Young Teachers in Private Colleges}

1) Most of young teachers respect and love their post, yet the professional ethics of a small number of them needs to be 
enhanced: Most of young teachers say they love the teaching profession with enthusiasm for work and they are serious and responsible, they work conscientiously, love students, impart knowledge and educate people. However, there are a small number of teachers who do not love education not the students; they just regard this work as a job for living, without practice and diligence. There are even very few young teachers who receive gifts from students taking advantage of their position, violating the professional ethics of teachers.

2) Young teachers have a complex teaching task without systemic career planning: Private colleges employ large number of young teachers to satisfy the demand of colleges' teaching task. Under the circumstances that there is relatively small amount of experienced teachers, young teachers shall shoulder plenty of teaching tasks when they hold the position of teacher, plus they have limited teaching experience, especially lack of guidance of experienced teachers, most young teachers say they have high pressure of work, and they should struggle to cope with various works every day. Private colleges have heavy teaching tasks, and teachers are busy in teaching and scientific research each semester, without energy and opportunity to participate in the academic conference, professional training and further study. As a result, they have difficulties in development and enhancement of their own profession, having no energy to plan their own profession development systematically.

\section{3) Lack of job security with poor professional identity}

Private colleges have flexible school-running mechanism, but have great risk of school-running due to lack of fund support from the state. Young teachers in private colleges have insufficient job security and poor sense of belonging except their high education background and wide range of employment opportunities. A small number of teachers do not love this job, and they just regard it as a spring-board of their career, looking for other jobs while holding this one, making them unable to keep their mind on in their job.

\section{ANALYSIS OF THE FACTORS OF PROFESSIONAL SPIRIT DEFICIENCY OF YOUNG TEACHERS IN COLLEGES}

The mainstream of professional spirit of young teachers in private colleges is worthy to be confirmed facing the demand of the times, but the hidden worries should not be ignored. Some teachers in private colleges have ideological confusion of different degree, and the phenomenon of absence of ideals and beliefs, displacement of value pursuit and dislocation of behavior also exist, which reflect in weakening of the sense of professional mission, inconformity of ethics cognition and behavior level; lack of professional dedication with serious utilitarian tendency; low profession identity and obvious contrast of occupational emotion identity; fading of professional passion with serious job burnout phenomenon; indifferent professional beliefs and great difference of occupational happiness. The reasons for the phenomenon are listed below:

\section{A. Ideal and Faith Deviate from World Outlook, Outlook on Life and Values}

As for the teachers in private colleges, the sense of career mission is the essence of ideal and faith, and the powerful spiritual motive force for overcoming difficulties, making efforts to exploit, improving the teachers' moral characters level and professional ability and making contributing to the realization of "Chinese Dream". Currently, influenced by the exam-oriented education, young teachers tend to strengthen individual's intellectual awareness for their development, yet the cultivation of moral quality is often neglected. Some private colleges pay attention to the professional ability improvement of young teachers but neglect the cultivation of professional ethics. Multiple social thoughts is impacting and influencing the world outlook, outlook on life and values of college young teachers, and capture the dominant right of teachers' professional spirit though utilitarian especially due to social transformation, times transformation and the fundamental changes in economic structure and lifestyle. Although the mainstream of values of young teachers remains unchanged in the essence, the professional spirit is changing and displacing subtly. The harmful social thoughts such as money worship, hedonism and individualistic doctrine are flourishing, which are reflected in a series of changes such as attaching importance to material and money, influencing teachers' professional values, professional attitude and professional behavior to a certain extent.

\section{B. Contrast between Professional Requirements and Reality of the Posts}

Teaching is a profession having high requirements for the individual's professional quality and comprehensive quality. Teacher is the one with high knowledge, which means that there are requirements for a teachers in terms of pedagogy, psychology, sociology and even literature and history in addition to the professional knowledge. Moral integrity refers to the right guidance, paying attention to the professional spirit. The traditional "candle" spirit of teachers expects teachers to reach the ideal condition of self-sacrifice, which view is short of reality under the current social condition and is harmful to the identification and internalization of professional spirit of young teachers in private colleges, impacting teachers' enthusiasm toward work. Such requirement even makes some young teachers have sense of fear and awe, causing a certain psychological stress and job burnout.

\section{Difference between Social Status and Economic Status}

The income gap between different regions, industries and occupations is widened obviously with the deepening of reform and opening up and the development of market economy and the evaluation criteria on profession by the society has also tilted to the economic status. Influenced by the unhealthy atmosphere within the college and society, interests and money test the reason for the existence of respecting teacher and his teaching constantly, affecting the recognition of teachers' social status and lowering teachers' sense of dignity and honor to a certain extent. The profession of college teacher loss its attraction to excellent social talents gradually, and influences the stability and development of teacher troops. 
Private college teachers have low remuneration, with the economic status to be improved a lot, making young teachers unbalanced mentally, confused and even loss and unavoidably doubt about their profession.

\section{Heavy Working Pressure and Living Burden}

The distribution system of college is not reasonable, being lack of powerful guarantee of distribution policy, which limits the income of young teachers. Moreover, the working time and space of young teachers in private college is extensive, with complex working content, high requirement and much more time energy to be input, but the teachers cannot obtain corresponding remuneration through their own hard work and excessive work. In addition, young teachers should constantly improve their educational background and academic level while shouldering the heavy teaching task and striving to study teaching skills. They shall overcome multiple difficulties from family and work in the course of work and study. Young teachers are more and more puzzled by physical and psychological stress, work and living burden and other issues.

\section{E. Lack of Main and Subjective Spirit}

The policy and system of private colleges tilt to the young teachers very limited, lacking of the normative channels and effective ways for young teachers to conduct democratic management, participate in school affairs democratically and express themselves. Young teachers are limited by other internal and external authorities of the college when handling the routine businesses. They should follow the system on the one hand, and they are required to make corresponding judgment based on their profession, causing obvious role conflict. There are many defects in the promotion system of teachers, and segments such as selection, assessment, recruitment and flow of teachers are lack of orderly competition. Young teachers have few chances of further study, insufficient platform to give play to their talents, and their development space and changes are limited. Under current college management system, the enthusiasm of young teachers will not be motivated, but the excessive competition among teachers will be induced, which will influence the professional spirit condition of teachers.

IV. THE Following STRATEGIES ARE PUT FORWARD AGAINST THE WAYS AND METHODS FOR THE CULTIVATION OF PROFESSIONAL SPIRIT OF YOUNG TEACHERS IN PRIVATE COLleges:

\section{A. The Government Provides Policy Support for Private Colleges to Guide the Construction of Beneficial Social Environment}

- At the time of promulgating relevant documents including the codes of professional ethics for teacher, the government shall make correct positioning of professional spirit of young teachers in private colleges, enabling the young teachers in private college to make clear the standard and specific requirements of professional requirements, so as to enhance this special group's occupational recognition and internalization level.
- The government should be humane when advocating the professional spirit of young teachers in private colleges, offering humanistic concern to young teachers from the aspects of material and spirit. The traditional professional spirit of teachers stresses "candle" spirit, hoping teachers to reach the ideal condition of self-sacrifice yet neglecting the personality and internal need of college young teachers, which view is short of social reality under the current condition of market economy and is harmful to the identification and internalization of professional spirit of young teachers in private colleges, impacting teachers' enthusiasm toward work. Such requirement even makes some young teachers have sense of fear and awe, causing a certain psychological stress and job burnout.

As a result, while formulating policies and systems, the government should take full consideration that young teachers in private colleges are also the main body of education, pay attention to the importance of them in the course of education, regard young teachers as a social man having self-demand, enabling them to satisfy the demand of self-realization while teaching and practicing the service spirit, in this way they can fully aware of the happiness of this job and make efforts to pursuit the professional ideal; in addition, government should act as the guidance of public opinions, to improve the social status of young teachers in private colleges, making more people treat them with tolerant and positive attitude. A society with the spirit of respecting teachers has the hope of continuous development.

\section{B. Private Colleges Shall Strengthen the Management and Education of Young Teachers and Highlight Their Subjectivity}

- Young teachers should be entitled to the school management, such as employment of teachers, professional title assessment, continuing education, evaluation system of teachers, promotion system and allotment of teachers and students. On the one hand, it reflects the democracy of private college management, and on the other hand, it can strengthen young teachers' job satisfaction and sense of teaching efficacy. Moreover, private colleges should educate young teachers regularly in terms of ideology and politics, so as to improve their ideological and political accomplishment and realize that young teacher is the one with both high knowledge and moral integrity" as soon as possible.

- With respect to system construction, private colleges shall formulate and improve the sound training system, evaluation system, motivation system and elimination system, create a campus cultural environment with positive competition and virtuous cycle, motivate young teachers' working initiatives, promote the benign development of young teachers, strengthen young teachers' crisis awareness, urge young teachers to adapt to their position in private colleges as soon as possible, so as to perform the effective and beneficial education and teaching in combination with the private 
colleges' development characteristics and the features of students in private colleges.

- Private colleges shall provide young teachers sufficient support in terms of material and spiritual aspects, for instance, to calculate the labor remuneration based on young teachers' labor value in teaching research. In addition, offer sufficient chances of further study and promotion, take full consideration of young teachers' demands in terms of housing and children education, so as to free them from worries. Leaders shall give more concern to young teachers' work status and living conditions, chat more with the young teachers, understand their individual demand, so as to satisfy their spiritual demand.

\section{Teachers Shall Strengthen Self-Education, Promote the Enhancement of Their Own Professional Spirit}

The key to establish positive professional values and cultivate lofty professional spirit is to rely on teachers themselves.

- First of all, young teachers in private colleges shall establish lofty professional ideal and they shall have the ambition, aspiration and pursuit to be engaged in education, so as to generate huge spiritual strength, which is the fundamental power to be persisted in education.

- Young teachers in private colleges shall also make efforts to improve their own quality cultivation. As the old saying goes that teacher is the one with both high knowledge and moral integrity. Young teachers' thoughts, behavior, style and moral character influence students subtly in addition to imparting knowledge. So teachers' role as the example cannot be ignored.

- Young teachers in private colleges shall pay attention to take care of students. In the course of teaching and education, they shall adhere to the idea of putting people first, teach students the principle of human behavior and pay attention to students' internal need, satisfy students' individualized demands without violating the principle, enter into students' spiritual world and influence students with personality charm, so as to be able to consider others and such education can yield twice the result with half the effort.

\section{CONCLUSION}

Today, the professional spirit of college teachers is valued, so the connotation and component of professional spirit cultivation of college young teachers should be diversified and advanced. When strengthening the study and discussion of theoretical level of professional spirit cultivation of young teachers in private colleges, the beneficial elements of multiculture should be absorbed, to enrich the connotation of professional spirit cultivation of young teachers, develop and construct vigorously the learning community and practice community of young teachers in private colleges, pay attention to push and lead the scientific cultivation of professional spirit of young teachers in private colleges from the perspective of practice, make efforts to include such education into practical, normalized, standardized, institutionalized, scientific and self conscious track. Teaching is not only a profession, but also a cause. Each teacher's love of this cause and unremitting efforts for this cause is the best explanation of teachers' professional spirit.

\section{REFERENCES}

[1] Liang Huiyin, Yang Sujuan. Research Overview of Professional Spirit of Modern Teachers [J]. Communication of Vocational Education, 2013(31):75

[2] Shuai Qin. On the Professional Spirit of Modern Teachers [D]. Nanchang: Jiangxi Normal University, 2008:7.

[3] Liu Guoxi. On the Cultivation of Professional Dedication Spirit of Yong Teachers of Ideological and Political Theory in Colleges [J]. Studies In Ideological Education, 2009(6):71-72.

[4] Yu Weizeng, Cai Wenlan. Cultivation of Teachers' Professional Dedication Spirit and Moral Motivation [J]. Chinese Adult Education, 2008(10):47.

[5] Sun Kaixiang. On Professional Spirit of College Teachers [J]. Journal of Mudanjiang Normal University(Philosophy Social Sciences Edition), 2013(1):137-138 